\title{
Familial Hypercalciuric Hypocalcemia
}

National Cancer Institute

\section{Source}

National Cancer Institute. Familial Hypercalciuric Hypocalcemia. NCI Thesaurus. Code C123261.

A hereditary condition caused by calcium sensing receptor gene mutations, resulting in calcium-hypersensitivity, and compensatory hypocalcemia and hypercalciuria. 